\title{
Hodgkin's lymphoma. II: Treatment and delayed morbidity
}

\author{
Patrice Carde
}

This is the eleventh in a series of articles examining recent developments in cancer

\section{Service de Médecine} C S Axel Unit, Institut Gustave-Roussy, 94805 Villejuif, France

Patrice Carde, head of department

Series edited by: Dr G M Mead.

BMF 1992;305:173-6
The increasing efficacy of treatment of Hodgkin's disease is best reflected by the improvements in relapse free survival which have occurred during the past 20 years, particularly in advanced disease; by contrast survival has improved little.'

\section{Radiotherapy}

Until recently radiotherapy was considered the only treatment with curative potential for disease limited to nodal areas, either localised (stages I-II) or more extensive (stage III). ${ }^{2}$ Cure was possible once adequate standards were met concerning the extent of the fields, the dose, and the availability of adequate energy beams.

The contiguous mode of dissemination of Hodgkin's disease along the lymphatic chains accounts for the prolonged restriction of invasion to non-vital areas and for the ability of regional irradiation to cure patients. The technique of extended field radiotherapy proposed by Gilbert as early as 1925 has not been seriously challenged since the first results in a large series by Kaplan in 1962. Extended field techniques treat the next contiguous area, which is thought "likely" to be affected-for example the mantle and inverted $\mathrm{Y}$ fields. Kaplan has shown a dose-response relation for the permanent control of any affected nodal areas. ${ }^{3}$ The ideal dose was found to be 40-44 Gy, but dosimetry calculations have shown wide variability in the dose actually received by patients within individual centres. Treatment of all fields daily with fractionation into, at most, five $1 \cdot 50-2 \cdot 00$ Gy fractions a week is crucial to avoid pulmonary and gastrointestinal radiation injuries. The introduction of adjuvant chemotherapy may have modified the doses required for sterilising affected nodes with ionising radiation. Children, in particular, have benefited from these new approaches, the widespread use of chemotherapy enabling lower

TABLE I - Main chemotherapy regimens for Hodgkin's disease

\begin{tabular}{|c|c|c|c|c|}
\hline Drugs & Dose $\left(\mathrm{mg} / \mathrm{m}^{2}\right)$ & Route & Scheme & Regimen \\
\hline $\begin{array}{l}\text { MOPP: } \\
\text { Mustine } \\
\text { Vincristine } \\
\text { Procarbazine } \\
\text { Prednisolone }\end{array}$ & $\begin{array}{l}6 \\
1 \cdot 4 \\
100 \\
40\end{array}$ & $\begin{array}{l}\text { Intravenous } \\
\text { Intravenous } \\
\text { Oral } \\
\text { Oral }\end{array}$ & $\begin{array}{l}1 \text { and } 8 \\
1 \text { and } 8 \\
1 \text { to } 14 \\
1 \text { to } 14\end{array}$ & $\begin{array}{l}28 \text { Day cycle }-2 \text { weeks' treatment, } \\
2 \text { weeks' rest. } \\
6 \text { Cycles for adjuvant treatment } \\
\text { and } 6-12 \text { for therapeutic }\end{array}$ \\
\hline $\begin{array}{l}\text { ABVD: } \\
\text { Doxorubicin } \\
\text { Bleomycin } \\
\text { Vinblastine } \\
\text { Dacarbazine }\end{array}$ & $\begin{array}{r}25 \\
10 \\
6 \\
375\end{array}$ & $\begin{array}{l}\text { Intravenous } \\
\text { Intravenous } \\
\text { Intravenous } \\
\text { Intravenous }\end{array}$ & $\begin{array}{l}1 \text { and } 15 \\
1 \text { and } 15 \\
1 \text { and } 15 \\
1 \text { and } 15\end{array}$ & $\begin{array}{l}28 \text { Day treatment cycle } \\
6 \text { Cycles for adjuvant treatment } \\
\text { and 6-12 for therapeutic }\end{array}$ \\
\hline $\begin{array}{l}\text { MOPP/ABV: } \\
\text { MOPP 1 week plus } \\
\text { Doxorubicin } \\
\text { Bleomycin } \\
\text { Vinblastine } \\
\text { Prednisone }\end{array}$ & $\begin{array}{r}35 \\
10 \\
6 \\
40\end{array}$ & $\begin{array}{l}\text { Intravenous } \\
\text { Intravenous } \\
\text { Intravenous } \\
\text { Oral }\end{array}$ & $\begin{array}{l}1 \text { to } 7 \\
\text { Day } 8 \\
\text { Day } 8 \\
\text { Day } 8 \\
8-14\end{array}$ & $\begin{array}{l}28 \text { Day cycle }-2 \text { weeks' treatment } \\
\text { and } 2 \text { weeks' rest. } \\
6 \text { Cycles for adjuvant treatment } \\
\text { and } 6-12 \text { for therapeutic }\end{array}$ \\
\hline $\begin{array}{l}\text { EBVP: } \\
\text { Epirubicin } \\
\text { Bleomycin } \\
\text { Vinblastine } \\
\text { Prednisone }\end{array}$ & $\begin{array}{r}75 \\
6 \\
6 \\
40\end{array}$ & $\begin{array}{l}\text { Intravenous } \\
\text { Intravenous } \\
\text { Intravenous } \\
\text { Oral }\end{array}$ & $\begin{array}{l}\text { Day } 1 \\
\text { Day } 1 \\
\text { Day } 1 \\
1 \text { to } 5\end{array}$ & $\begin{array}{l}21 \text { Day treatment cycle } \\
6 \text { Cycles for adjuvant treatment }\end{array}$ \\
\hline $\begin{array}{l}\text { VBM: } \\
\text { Vinblastine } \\
\text { Bleomycin } \\
\text { Methotrexate }\end{array}$ & $\begin{array}{r}6 \\
10 \\
30\end{array}$ & $\begin{array}{l}\text { Intravenous } \\
\text { Intravenous } \\
\text { Intravenous }\end{array}$ & $\begin{array}{l}1 \text { and } 8 \\
1 \text { and } 8 \\
1 \text { and } 8\end{array}$ & $\begin{array}{l}28 \text { Day cycle }-2 \text { weeks' treatment } \\
\text { and } 2 \text { weeks' rest. } \\
6 \text { Cycles for adjuvant treatment }\end{array}$ \\
\hline $\begin{array}{l}\text { CEP: } \\
\text { Lomustine } \\
\text { Etoposide } \\
\text { Prednimustine }\end{array}$ & $\begin{array}{r}80 \\
100 \\
60\end{array}$ & $\begin{array}{l}\text { Oral } \\
\text { Oral } \\
\text { Oral }\end{array}$ & $\begin{array}{l}\text { Day } 1 \\
\text { Day l to } 5 \\
\text { Day } 1 \text { to } 5\end{array}$ & $\begin{array}{l}28 \text { to } 46 \text { day cycle } \\
6-8 \text { Cycles for salvage treatment }\end{array}$ \\
\hline
\end{tabular}

radiography doses (20-30 Gy) to be given to restricted volumes (avoiding the humeral joints, left ventricle, lungs, etc) so that subsequent abnormalities in growth and function are limited. ${ }^{+}$Technical advances (computed tomography, treatment planning, field simulation, portal imaging, custom contoured cerrobend blocks, opposed field techniques, field modification during treatment, and quality assurance programmes) have made it possible to deliver high radiation doses $(6 \cdot 25 \mathrm{MeV}$ linear accelerator photons) to deep tissues while sparing unaffected superficial tissues. Further developments have allowed superficial treatments with limited penetration (electron beams from linear accelerators).

\section{Chemotherapy}

The efficacy of chemotherapy can be assessed more easily in advanced Hodgkin's disease (stages IIIB-IV), than in localised disease because chemotherapy represents the main treatment and relapses are frequent. Three main chemotherapy regimens have been tested: MOPP (mustine, vincristine, procarbazine, and pred nisolone), AVBD (doxorubicin, bleomycin, vinblastine, and dacarbazine), and a combination of both (tables I and II). MOPP, the standard chemotherapy, alternates two week cycles of treatment (intravenous and oral) with rest periods, which allow recovery from the serious toxicity usually experienced. ${ }^{17}$ Adequate dosing has an impact on the results, ${ }^{18}$ and usually not more than eight cycles need to be given. Derivatives of MOPP may be better tolerated, particularly when mustine is replaced by chloram bucil. $^{10}$ Cures with ABVD in patients who have relapsed after treatment with MOPP provided evidence that salvage with chemotherapy could be achieved in patients in whom a first induction regimen failed. ${ }^{19}$ Only the Cancer and Leukaemia Group B (CALGB) directly compared MOPP and ABVD in advanced Hodgkin's disease. Its study showed a significantly higher relapse free survival with ABVD ${ }^{8}$ This finding was confirmed when ABVD was compared with MOPP in patients also receiving radiotherapy for localised Hodgkin's disease. ${ }^{2021}$

In EBVP, a popular ABVD derivative, in which epirubicin has been substituted for doxorubicin; dacarbazine was dropped from the regimen because of its equivocal efficacy and serious gastrointestinal toxicity. ${ }^{22}$

A benefit was expected from the combination of MOPP and a derivative of ABVD ${ }^{14}$ The superiority of the combination over MOPP alone was shown by the European Organisation for Research and Treatment of Cancer and the CALGB trial. ${ }^{78}$ The mechanism underlying the combination's greater effect was investigated by the CALGB trial by adding a third arm-ABVD alone-and by the Société Française d'Oncologie Pediatrique trial in children: the combination was not superior to ABVD alone, suggesting that ABVD is intrinsically more efficient than MOPP. This hypothesis is supported by the design of the CALGB trial, in which an unbalanced number of cycles (12 of MOPP/ABVD $v$ six of ABVD) may have favoured the combination. ${ }^{8}$ The assessment of new ABVD derivatives should therefore be given the highest priority. 
Treatments that may result in delayed death after Hodgkin's disease
Treatment

Laparotomy

Nitrogen mustard, etoposide

Bleomycin plus mediastinal irradiation

Radiotherapy of left ventricle other alkylating drugs,
Possible adverse effects

Embolism and sepsis and perhaps secondary leukaemia and solid tumours

Secondary leukaemia

Lung fibrosis

Cardiac complications in young patients ${ }^{202326}$

\section{Prevention of lethal toxicity}

Only recently has it been appreciated that treatmen related toxicity has jeopardised long term survival in substantial proportions of patients. ${ }^{23-25}$ The relative risk of death in patients cured of Hodgkin's disease was over three times that in the general population in the European series. ${ }^{25}$ In the international database series only $6 \%$ of the deaths in patients without evidence of active Hodgkin's disease were recorded as treatment related, with these deaths occurring mostly in the first 10 years. ${ }^{24}$ However, treatment probably contributed to many of the deaths attributed to an unspecified cause $(3 \%)$, intercurrent disease (14\%), and secondary cancer $(10 \%) .{ }^{1}$ The box lists the potentially lethal factors that can be avoided.

It seems likely that the current and fashionable introduction of more intense treatments (high dose chemotherapy or radiotherapy, or both, before autologous marrow or peripheral stem cell transplantations) in large cohorts of patients (supposedly at high risk or as a "consolidation" measure) will cause a significant incidence of delayed death in 10 years' time. Similarly, inhibitors of topoisomerase II (such as etoposide) have recently been increasingly used; these may be responsible for secondary leukaemias associated with balanced translocations. ${ }^{27}$ Finally, radiotherapy is probably responsible for most of the secondary solid tumours: reduced field sizes and possibly dose tapering should be explored. ${ }^{24} 28$

\section{Assessment and prevention of delayed morbidity}

No sufficiently sensitive tests are at present available to allow monitoring of cardiac and pulmonary risks; this is shown by the disappearance after two years of follow up of initial differences between patients treated with mantle irradiation plus MOPP or ABVD. ${ }^{20}$ However, long term follow up of cohorts of patients treated with heart irradiation or anthracyclines, or both, may show persisting effects, as seen recently in children. This issue is being investigated.$^{23}$ Efforts are underway to select the least toxic regimens or to investigate the possibility of using drugs with a potentially cardioprotective effect - for example, free radical scavengers or the ferrous chelator razoxane $187 .{ }^{29}$

Unfortunately, gonadal toxicity has rarely been monitored accurately in either sex and few efforts have been made to avoid the alkylating drugs responsible for this problem. Gonadal protection from radiotherapy has also been suboptimal, and few of the potential protectors are being tested. ${ }^{30}$ Sperm storage is not offered to all patients, indicating that medical staff are not well informed.

These issues are particularly important in children, where the freedom from progression and survival figures are generally better than those observed in adults. In children chemotherapy alone remains a valid option owing to the problems with growth associated with radiotherapy. Gonadotoxicity and leukaemogenicity remain problems, despite which alkylating drugs are still widely used. ${ }^{31}$ The risk of long term toxicity, including cardiac and gonadal damage, should increasingly influence the choice of drugs.

\section{New approaches to early stage disease}

The use of different historical databases may explain why no consensus has emerged for treating localised supradiaphragmatic Hodgkin's disease. ${ }^{32}$ Only prominent general recommendations are possible in reference to recent and ongoing clinical trials: for example, staging laparotomy is not necessary, stratification to tailor both investigation and treatment to pretreatment characteristics should avoid undertreatment and overtreatment, and prolonged follow up is essential to identify delayed toxicities. Since few events occur in early stage disease attempts to establish prognostic groups and indexes must rely on large

TABLE II - Main chemotherapy results in Hodgkin's disease

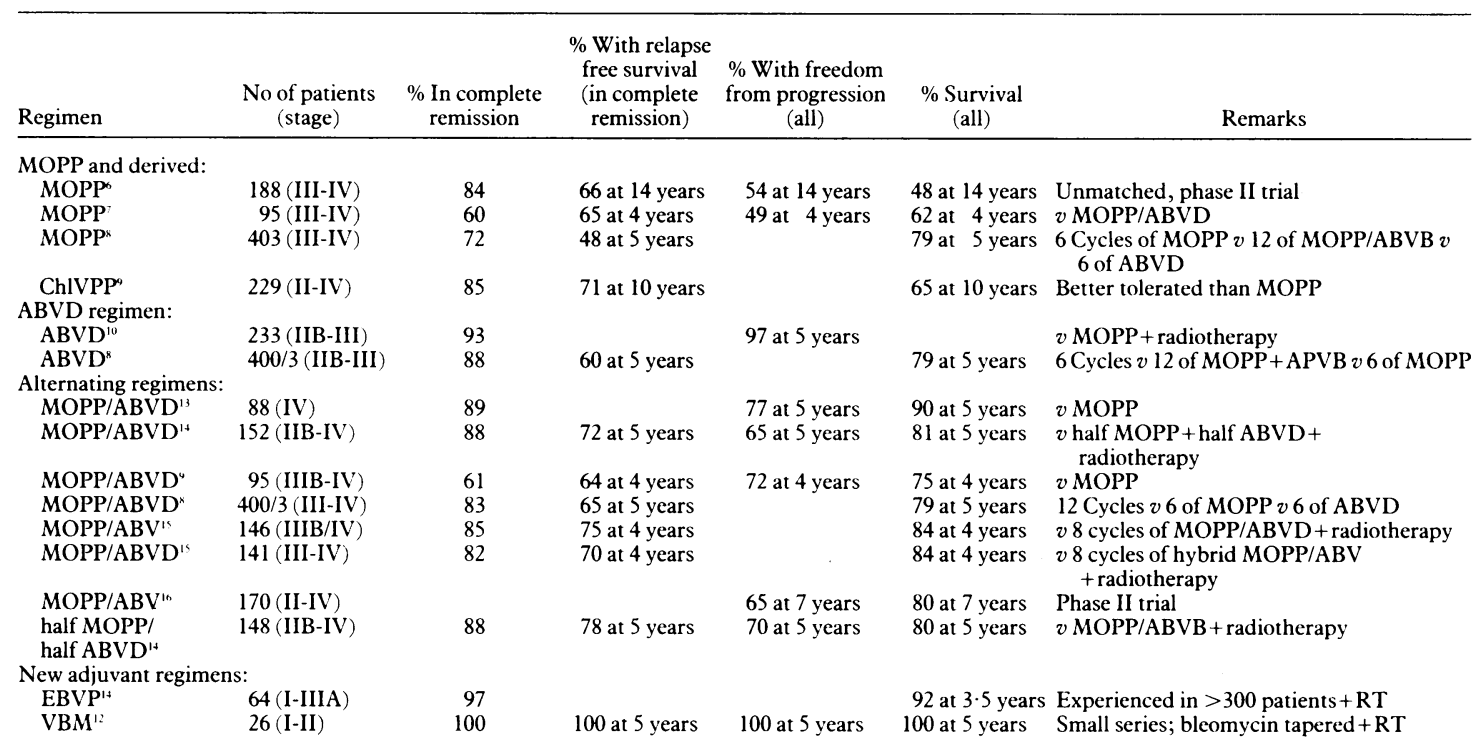


cohorts of patients with prospectively registered initial characteristics and must take into account the type of staging and treatment used. Some prognostic factors are simple enough to be of practical help: systemic (B) symptoms, erythrocyte sedimentation rate, tumour bulk expressed as the number of nodal sites affected or as the size of the mediastinal mass, and older age. ${ }^{3+36}$

A practical strategy to adjust treatment intensity to likely response might be one recognising four prognostic groups arbitrarily separated. In the very favourable group (for instance, stage I lymphocyte predominant Hodgkin's disease affecting high cervical nodes in women) the only treatment necessary may be supradiaphragmatic radiotherapy. In favourable patients and even in unselected patients who have not had a laparotomy subtotal nodal irradiation is acceptable. ${ }^{5233} 33^{378}$ In such patients adjuvant vinblastine used alone provided a persisting advantage in freedom from progression without an increase in secondary leukaemias. ${ }^{39}$ This observation supports the use of low toxic adjuvant regimens such as the VBM (vinblastine, bleomycin, and methotrexate) or EBVP in such cases. ${ }^{22}{ }^{40}$ One study found that chemotherapy alone provided equivalent results to chemotherapy and radiotherapy in favourable patients but inferior results in unfavourable patients. ${ }^{41}$ In unfavourable patients most randomised trials have shown superior freedom from progression with combined chemotherapy and radiotherapy to that with radiotherapy alone, though a survival advantage has not been shown. ${ }^{32}$ Metaanalyses are being conducted to investigate this question on a broader database. Adjuvant ABVD has proved better than MOPP in all available randomised trials. $^{2021}$ Finally, a very unfavourable group has not yet been satisfactorily defined. For patients with large mediastinal masses, who clearly belong to this group, both radiotherapy alone and MOPP alone are suboptimal, ${ }^{42-45}$ making comparisons of chemotherapy alone with radiotherapy alone less attractive. The two trials which compared MOPP alone with radiotherapy alone provided contradictory results..$^{145}$

Older age is the most adverse prognostic factor, although age has not been proved to be associated with a more aggressive disease pattern. Ways to deliver more effective chemotherapy and radiotherapy in patients over 65 are being investigated.

\section{Marrow transplantation}

The reported efficacy of any salvage chemotherapy regimen must take into account the case mix, in particular, both the time to relapse and the type of chemotherapy previously administered. For failure of treatment with MOPP and its derivatives the best results to date $(20 \%$ freedom from progression at five years) have been reported with ABVD. ${ }^{19}$ Conversely, MOPP has proved less effective in patients in whom ABVD had failed. ${ }^{1+}$ After sequential or alternating MOPP/ABVD few conventional dose salvage regimens have proved effective. The best results have been reported with the CEP (CCNU (lomustine), etoposide, and prednimustine) regimen $(47 \%$ rate of complete remission with $20 \%$ survival at five years). ${ }^{46}$ Monochemotherapy may offer valuable palliation in those patients in whom salvage chemotherapy fails and who are not eligible for high dose chemotherapy. ${ }^{47}$

High dose chemotherapy-for instance, CBV (cyclophosphamide, carmustine, etoposide) followed by autologous bone marrow transplantation ${ }^{48}-$ is an alternative approach. In one study complete remission and three year survival rates over $50 \%$ and $30 \%$ respectively were reported in heavily pretreated patients. ${ }^{+8}$ However, lethal toxicities do occur with this approach (in $17 \%$ of patients in the large European autologous bone marrow transplantation series). ${ }^{49}$
Patients unsuitable for transplantation include those in whom complete remission has never been achieved, those who have had previous extensive irradiation, or, in some centres, those in a second complete remission. The overall impact of autologous bone marrow transplantation is unknown as patients treated with this method are usually highly selected for the procedure. ${ }^{+9}$ The use of peripheral blood stem cells and growth factors in addition to or in place of autologous marrow may help haematological tolerance. ${ }^{5051}$ Several European trials are now randomising bone marrow transplantation and conventional chemotherapy in well defined patients with relapse after in field radiotherapy or after MOPP plus ABVD or an equivalent regimen. Long term toxicities have yet to be well quantified.9 ${ }^{49}$ The procedure should not at this time be extended to patients who could be cured by other methods - that is, initially high risk patients who achieved a first remission and those with relapse after radiotherapy alone or radiotherapy combined with less intensive chemotherapy regimens.

\section{Conclusion}

The Cotswold revision of the staging classification should help to improve the management of Hodgkin's disease. Objective biological parameters need to be identified that can be used to predict the progression of the disease. These may emerge from the recent advances in knowledge of the disease's aetiology and pathogenesis. Broad data banks like that of the international database overview should improve assessment of the likely prognosis with treatment strategies of different severities. With these developments and the increased use of adjuvant chemotherapy staging laparotomy may no longer be used.

The apparent advantage of combined radiotherapy and chemotherapy over either treatment alone in early stage disease may be confirmed by ongoing metaanalyses. New approaches to early stage disease that combine low dose radiotherapy with non-toxic chemotherapy in an attempt to decrease the high death rate related to treatment seem more important. Although most of the drugs responsible for secondary leukaemia have been recognised (mustine, nitrosoureas, and etoposide), they are still included in regimens given to children and their use has not been restricted to high risk patients. That radiotherapy causes secondary solid tumours is well recognised, but the cardiovascular consequences of mediastinal irradiation are probably underestimated. Recent results from large randomised trials confirm that large patient cohorts, multicentre studies, and long term follow up are needed to improve the management of patients. The advances in treatment of Hodgkin's disease should benefit the entire specialty of oncology.

1 Somers R, Henry-Amar M, Meerwaldt JH, Carde P, eds. Treatment strategy in Hodgkin's disease. London, Paris: INSERM/John Libbey Eurotext, 1990 (Colloque INSERM No 196.)

2 Peckham MJ, Ford HT, McElwain JT, Harmer CL, Atkinson K, Austin DE. The results of radiotherapy for Hodgkin's disease. $\mathrm{Br}$ f Cancer 1975;32: $391-400$

3 Kaplan HS. Hodgkin's disease. Cambridge, Massachusetts: Harvard, 1980.

4 Dionet C, Oberlin O, Habrand JL, Vilcoq J, Madelain M, Dutou L, et al. Initial chemotherapy and low-dose radiation in limited fields in childhood Hodgkin's disease: result of a joint cooperative study by the French Hodgkin's dise study by the French Society of Pediatric Oncology (SFOP) and Hôpital Saint-Louis, Paris.

5 Hoppe RT. Radiation therapy in the management of Hodgkin's disease. Sem Oncol 1990;17:704-15.

6 Longo DL, Young RC, Wesley M, Hubbard SM, Duffey PL, Jaffe EF, et al 20 Years of MOPP therapy for Hodgkin's disease. I Clin Oncol 1986; 1296-306.

7 Somers R, Henry-Amar M, Carde P, Najman A. MOPP vs alternatin $2 \mathrm{MOPP} / 2 \mathrm{ABVD}$ in advanced Hodgkin's disease (HD). Proceedings of the American Society of Clinical Oncology 1988;914:236.

8 Cannellos GP, Propert K, Cooper R, Nissen N, Anderson J, Antman KH et al. MOPP vs ABVD vs MOPP alternating with ABVB in advanced Hodgkin's disease: a prospective randomised CALGB trial. Proceedings of the American Society of Oncology 1988;8:230.

9 Selby P, Patel P, Milan S, Meldrum M, Mansi J, Mbidde E, et al. ChIVPP 
combination chemotherapy for Hodgkin's disease: long term results. Br f Canc 1990;62:279-8

10 Santoro A, Viviani S, Zucali R, Ragni G, Bonfante V, Valagussa P, et al. Comparative results and toxicity of MOPP vs AVBD combined with radiotherapy (RT) in PSIIB, III (A, B) Hodgkin's disease (HD). [Abstract]. Proceedings of the American Society of Oncology 1983;2:223.

11 Zittoun R, Eghbali H, Audebert A, Rojouan J, David B, Blank CM, et al. Association d'epirubicine, bleomycine, vinblastine, et prednisone (EPVB) avant radiotherapie dans les stades localisés de la maladie de Hodgkin. Essa de phase II. Bull Canc 1987;74:1515-7.

12 Hoppe RT, Horning SJ, Hancock SL, Rosenberg SA. Current Stanford clinical trials for Hodgkin's disease. Recent Results Cancer Res 1989:117: $182-90$.

13 Bonadonna G, Santoro A, Valagussa P, Viviani S, Zucali R, Bonfante V, et al. Current status of the Milan trials for Hodgkin's disease in adults. In: Cavalli F, Bonadonna G, Rosencweig M, eds. Proceedings of the second international conference on malignant lymphomas, Lugano, Fune 13-14, 1984. Boston: conference on malignant lymphomas, Lugano,
Martinus Niihoff Publishing, 1985:299-307. 14 Bonadonna G, Santoro A, Gianni AM, Viviani S, Siena S, Gregni M, et al.
Primary and salvage chemotherapy in advanced Hodgkin's disease: the Milan Cancer Institute experience. Ann Oncol 1991;1:9-16.

15 Connors JM, Klimo P, Adams G, Burns B, Cooper I, Meyer R, et al. MOPP/ABV hybrid versus alternating MOPP/ABVD for advanced Hodgkin's disease. Proceedings of the American Society of Clinical Oncology 1992;11:317.

16 O'Reilly SE, Hoskins P, Klimo P, Connors JM. MACOP-B and VACOP-B in diffuse large cell lymphoma and MOPP/ABV in Hodgkin's disease. Ann Oncol 1991;2(suppl 1):17-23.

17 De Vita VT, Serpick AA, Carbone PP. Combination chemotherapy in the treatment of advanced Hodgkin's disease. Ann Intern Med 1970;73:891-5.

18 Carde P, Mackintosh FR, Rosenberg SA. A dose and time response analysis of the treatment of Hodgkin's disease with MOPP chemotherapy. 7 Clin Oncol 1983;1:146-53.

19 Santoro A, Bonfante V, Bonadonna G. Salvage chemotherapy with ABVD in MOPP-resistant Hodgkin's disease. Ann Intern Med 1982;96:139-43.

20 Carde P, Hagenbeek A, Hayat $M$, Monconduit $M$, Thomas J, Burgers MJV, et al. Clinical staging versus laparotomy and combined modality with MOPP versus ABVD in early stage Hodgkin's disease: the $\mathrm{H} 6$ twin randomized trials from the EORTC lymphoma cooperative group 1992 (in press).

21 Santoro A, Bonadonna G, Valagussa P, Zucali R, Viviani S, Villani F, et al. Long-term results of combined chemotherapy-radiotherapy approach in Hodgkin's disease: superiority of ABVD plus radiotherapy versus MOPP plus radiotherapy. $f$ Clin Oncol 1987;5:27-37.

22 Hoerni B, Orgerie MB, Eghbali H. Nouvelle association d'épirubicine, bléomycine, vinblastine et prednisone (EBVP II) avant radiothérapie dan les stades localisés de maladie de Hodgkin. Essai de phase II chez 50 malades. Bull Cancer 1990;75:789-94.

23 Hohl RJ, Schilsky RL. Non malignant complications of therapy for Hodgkin's disease. Hematol Oncol Clin North Am 1989;3:331-43.

24 Henry-Amar M, Somers R. Survival outcome after Hodgkin's disease: a report from the international data base on Hodgkin's disease. Sem Oncol 1990;17: 758-68.

25 Cosset JM, Henry-Amar M, Meerwaldt JH. Long-term toxicity of early stages of Hodgkin's disease therapy: the EORTC experience. Ann Oncol 1991;2 77-82.

26 Cosset JM, Henry-Amar M, Pellae-Cosset B, Carde P, Girinski T, Tubiana M, et al. Pericarditis and myocardial infarctions after Hodgkin's disease therapy at the Institut Gustave Roussy. Int $\mathcal{F}$ Radiat Oncol Biol Phys 1990;21:447-9.

27 Ratain MJ, Rowley JD. Therapy-related acute myeloid leukemia secondary to inhibitors of topoisomerase II: from the bedside to the target genes. Ann Oncol 1992;3:107-11

28 Tucker MA, Coleman CN, Cox RS, Varghese A, Rosenberg SA. Risk of second cancers after treatment for Hodgkin's disease. $N$ Engl $\mathcal{F}$ Med 1988;318:76-81.

29 Speyer JL, Green MD, Zeleniuch-Jacquotte A, Wernz JC, Rey M, Sanger J, et al. ICRF-187 permits longer treatment with doxorubicin in women with breast cancer. F Clin Oncol 1992;10:117-27.

30 Jégou B, Velez de la Calle JF, Bauché F. Protective effect of medroxyprogesterone acetate plus testosterone against radiation-induced damage progesterone acetate plus testosterone against radiation-induced damage
to the reproductive function of male rats and their offspring. Proc Natl Acad SciUSA 1991;88:8710-4.
31 Ekert H, Waters KD, Smith PJ, Toogood I, Mauger D. Treatment with MOPP or ChlVPP chemotherapy only for all stages of childhood Hodgkin's disease. $\mathcal{F}$ Clin Oncol 1988;6:1845-50.

32 Rosenberg SA, Kaplan HS: The evolution and summary results of the Stanford randomized clinical trials of the management of Hodgkin's disease: 1962-1984. Int F Radiat Oncol Biol Phys 1985;11:5-32.

33 Horwich A. The management of early Hodgkin's Disease. Blood 1990;4: 181-6.

34 Tubiana $M$, Henry-Amar $M$, Carde P, Burgers JMV, Hayat $M$, Van Der Schueren E, et al. Towards comprehensive management tailored to prognostic factors of patients with clinical stages I and II in Hodgkin's disease. The EORTC Lymphoma Group controlled clinical trials: 1964-1987. Blood 1989;73:47-56.

35 Specht L. Prognostic factors in Hodgkin's disease. Cancer Treat Rev 1991;18:21-53.

36 Haybittle JL, Hayhoe FG, Easterling MJ, Jelliffe M, Bennett MH, Vaugh Hudson G, et al. Review of British National lymphoma investigation of Hodgkin's disease and development of prognostic index. Lancet 1985; $967-72$.

37 Mauch BP, Tarbell N, Weinstein H, Silver B, Goffman T, Osteen R, et al. Stage IA and IIA supradiaphragmatic Hodgkin's disease: prognostic factors in surgically staged patients treated with mantle and paraaortic irradiation. f Clin Oncol 1988;6:1576-83.

38 Carde P, Burgers JMV, Henry-Amar M, Hayat M, Sizoo W, Van Der Schueren E, et al. Clinical stages I and II Hodgkin's disease: a specifically tailored therapy according to prognostic factors. $f$ Clin Oncol 1988;6: 239-52.

39 Carde P, Henry-Amar M, Tubiana M, Van Der Werf-Messing B, Henry J, Abbatucci $\mathrm{J}$, et al. No increased incidence of second leukemias in patients treated with vinblastine alone or associated with procarbazine following radiotherapy in 2 successive EORTC controlled trials (1964-1976) in clinical stages I-II Hodgkin's disease. Proceedings of the American Society of Clinical Oncology 1985;4:212.

40 Horning SJ, Hoppe RT, Hancock SL, Rosenberg SA. Vinblastine, bleomyci and methotrexate: an effective adjuvant in favorable Hodgkin's disease. and methotrexate: an effective

41 Pavlovsky S, Maschio M, Santarelli MT, Muriel FS, Corrado C, Garcia I, et al. Randomized trial of chemotherapy versus chemotherapy plus radiotherapy for stage I-II Hodgkin's disease. F Natl Cancer Inst 1988;80:1466-73.

42 Cosset JM, Henry-Amar M, Carde P, Clarke D, Lebourgeois JP, Tubiana $M$ The prognostic significance of large mediastinal masses in the treatment Hodgkin's disease. The experience of the Institut Gustave-Roussy. Hematol Oncol 1984;2:33-43.

43 Longo DL, Russo A, Duffey PL, Hubbard SM, Glatstein E, Hill JB, et al. Treatment of advanced-stage massive mediastinal Hodgkin's disease: the case for combined modality treatment. F Clin Oncol 1991; 9:227-35.

44 Longo DL, Glatstein E, Duffey PL, Young RC, Hubbard SM, Urba WJ, et al. Radiation therapy versus combination chemotherapy in the treatmen of early-stage Hodgkin's disease: seven-year results of a prospective randomized trial. F Clin Oncol 1991;9:906-17.

45 Cimino G, Biti GP, Anselmo AP, Enrici RM, Bellesi GP, Bosi A, et al. MOPP chemotherapy versus extended-field radiotherapy in the management pathological stages I-IIA Hodgkin's disease. F Clin Oncol 1989;7:732-7.

46 Bonadonna G, Valgussa P, Santoro A. Prognosis of Hodgkin's disease treate with chemotherapy alone or combined with radiotherapy. Cancer Sur $1985 \cdot 4: 439-58$

47 Mead GM, Harker WG, Kushlan P, Rosenberg SA. Single agent palliative chemotherapy for end-stage Hodgkin's disease. Cancer 1982;50:829-35.

8 Jaganath S, Dicke KA, Armitage JO, Cabanillas FF, Horwitz LJ, Vellekoop $L$, et al. High dose cyclophosphamide carmustine and epotoside and autologous bone marrow transplantation for relapsed Hodgkin's disease. Ann Intern Med 1986;104:163-8.

49 Goldstone $\mathrm{AH}$, Linch DC. Bone marrow transplantation in the malignan lymphomas. Recent advances in haematology 1992;6:149-71.

50 Kessinger A, Armitage JO, Smith DM, Landmark JD, Bierman PJ, Weisenburger DD. High dose therapy and autologous peripheral blood stem cell transplantation for patients with lymphoma. Blood 1989;74:1260-5.

51 Nemunaitis J, Rabinowe SN, Singer JW, Bierman PJ, Vose JM, Freedman $\mathrm{AS}$, et al. Recombinant granulocyte-macrophage colony-stimulating facto AS, et al. Recombinant granulocyte-macrophage colony-stimulating facto NEngl F Med 1991;324:1773-8.

\section{ANY QUESTIONS}

What is the recommended dose of aspirin for prophylactic use in patients who have had heart attacks, strokes, or cardiac surgery?

Pharmacological studies indicate that cyclo-oxygenase dependent platelet aggregation is inhibited long term jus as effectively by low daily doses - that is, $100 \mathrm{mg}$ or less of aspirin as by higher doses. Indeed, it has been suggested that the lower doses, by relative sparing of endothelial production of prostacyclin, might have greater antithrombotic effects, although this is disputed. In an overview of trials of antiplatelet treatment ${ }^{1}$ the observed reductions in the risk of important vascular events (vascular death, myocardial infarctions, and strokes) were at least as great in studies of lower daily doses of aspirinthat is, $300-325 \mathrm{mg}$ - as in studies of higher doses - that is, 500-1500 mg daily - and in the second international study of infarct survival a daily dose of $162 \mathrm{mg}$ of aspirin greatly reduced the risk of death, stroke, and reinfarction. Higher doses of aspirin are associated with more gastrotoxicity and intestinal bleeding than are lower doses.
Hence, there seems to be no good reason to use a daily dose of aspirin higher than 100-325 mg (perhaps an enteric coated tablet should be used to minimise gastric side effects) during long term treatment. Doses of less than $100 \mathrm{mg}$ may, however, take a few days before they produce their full antiplatelet effects ${ }^{3}$ - that is, more than $95 \%$ inhibition - so it may be prudent to start with a higher loading dose, such as $162-325 \mathrm{mg}$, when immediate effects are required, as in the initial treatment of acute myocardial infarction, unstable angina, or crescendo transient ischaemic attacks.-RORY COLLINS, senior research fellow, Oxford

1 Antiplatelet Trialists' Collaboration. Secondary prevention of vascular disease by prolonged antiplatelet treatment. BMF 1988;296: 320-31.

2 ISIS-2 (Second International Study of Infarct Survival) Collaborative Group. Randomised trial of intravenous streptokinase, oral aspirin, Group. Randomised trial of intravenous streptokinase, oral aspirin,
both, or neither among 17187 cases of suspected acute myocardial both, or neither among 17187 cases
infarction: ISIS-2. Lancet 1988 ;ii:349-60.

3 Clarke RJ, Mayo G, Price P, FitzGerald G. Suppression of thromboxane A but not of systemic prostacyclin by controlled-release aspirin. $N \mathrm{Engl} f$ Med 1991;325:1137-41. 